\title{
My Secondary Modern: stories from the invisible generation
}

\author{
EMMA-LOUISE WILLIAMS \& MICHAEL ROSEN
}

\begin{abstract}
One of the least recorded and analysed aspects of English and Welsh education is the personal experience of millions of people attending secondary modern schools following the 1944 Education Act. Since 2012, Emma-Louise Williams and Michael Rosen have hosted a moderated blog for self-selecting personal testimony from anyone involved. So far, some 90 people have contributed posts or comments and the blog has received approximately 100,000 views. This article reviews the material while bearing in mind its particularity.
\end{abstract}

The dominant narratives of secondary modern education use a vocabulary of failure. However, $75 \%$ of children attended a secondary modern school after the 1944 Butler Act, and their experiences were varied and valuable.

There is no national conversation about how this majority experienced the all-deciding exam, its outcome, the experience of the 'secmod' school and, perhaps most important of all: what life has been like since. At a time when once again life-changing decisions are about to be made in relation to education, we do not know what happened to the majority of people who grew up in England and Wales in the 1940s, '50s, '60s and '70s and who are now anything from 50 to 85 years old. This was a life-changing experience for several generations and yet it's a story that hasn't been told.

\section{Untold. Unheard.}

In 2012, we (Michael Rosen and Emma-Louise Williams) set up a blog so that people who had attended or worked in secondary modern schools in the era following the 1944 Education Act could put their memories into a public space. The blog is structured quite simply: people can offer a testimony and/or make comments. All posts are moderated by Emma. 
We were motivated to do this by several impulses. First, the belief that the history of post-war education was unevenly and incorrectly told. It has largely been related in the media and in books as the history of a minority: those who attended private and grammar schools. In its own way, this means that the account we are most familiar with is a social or civil version of 'history as told by the victors'.

The effect of knowing that one's history is untold and unheard is cumulative. Without explanation, a part of one's life becomes marginalised or disappeared. This feeds into a sense of shame or failure. We have to remember clearly how the 1944 Act was enacted. A crucial, high-stakes exam administered in children's sixth year of formal statutory education (i.e. at the age of 10 or 11) decided whether you went to grammar school, a technical school, or a secondary modern school. It is clear from the testimonies (below) that a combination of failing the exam and the segregation that followed weighed heavily on many pupils. Further, that this sense of shame and failure has never left many of these people. To be clear, this shame was constructed within and by sibling relationships, nuclear families, wider families, localities and ultimately nationally. This was, after all, a national exam pursued for national objectives impacting on people as individuals.

We are living in a time when a conversation is once more taking place around grammar schools. The main party in power for the last seven years has within it clear and loud voices advocating the re-introduction of grammar schools. Quite apart from the educational arguments about this, there are political problems. A universally applied 11-plus-type exam will impose a nongrammar school education on children whose parents may well be supporters of the Conservative Party. Again, it is worth remembering that ex-grammar school pupil Margaret Thatcher took crucial steps in her time as prime minister to hasten the conversion of most schools in most areas to become comprehensives. It wasn't a one-off act by a Labour government. One of the reasons why Margaret Thatcher was apparently so willing to 'let the grammar schools go' was that she knew full well how unpopular secondary modern education was among many of her supporters, often described as the 'aspiring working class'. In fact, it's a clear memory of Michael Rosen, who attended state primary schools from 1951 until 1957, how fearful middle-class parents (not only aspiring working-class ones) in the London suburbs were that their children might end up in the local secondary modern school - as indeed some did.

\section{'Disappearing' the Secondary Modern Experience}

The arguments circulating around the Conservative Party in favour of expanding or bringing back a full-blooded universal grammar school system focus on two justifications: that it enabled social mobility in the past, and that it enables high fliers to get on better today.

The social mobility argument is erroneous for two reasons. The period following the 1944 Education Act was one of an expanding economy, which 
both promoted layers of society that had previously been excluded from those echelons and drew in migrants who filled places in society previously occupied by those who had little education. Furthermore, 'social mobility' in any given population is a misconception. Some kind of true social mobility would require people to move out of the way in the upper echelons to allow for other people to move in. In fact, places in the upper echelons of society are secured by a combination of inherited wealth, private education and tax avoidance.

The high-fliers argument, too, isn't borne out by the statistics, which have never been able to show that the supposed benefit derived from attending a grammar school is worth anything significant in grade terms in comparison with the exam performance attained in comprehensive schools. However, in arguing on this basis (as we are here), it is easily forgotten that education serves the purpose of benefiting society, not just individuals. Segregating pupils in terms of their actual or supposed ability does nothing for society's need for people who relate well to each other across ability, culture, ethnicity, gender, bodily ability and so on.

By focusing on the secondary modern experience, we also draw attention to one glaringly obvious but often ignored fact lying behind the re-introduction of grammar schools: it involves the re-introduction of non-grammar schools whatever form they take. This is a matter of urgency. One of the side effects of 'disappearing' the secondary modern experience is that it distorts the way commentators and writers tell the story of 'bringing back grammar schools'. They tell it as if this is a policy which only involves grammar schools and its pupils. It singularly fails to see the whole picture: one in which the majority of pupils are labelled at the age of 11 as unsatisfactory. What is truly absurd about this is that the use of one single label and one sole destination (the given school) as an indicator of a whole person's mixed bag of abilities, potentials and qualities is deeply flawed as an educational concept. To then impose that flawed model on the 'failing' child's five or seven years of compulsory education is an injustice. In fact there were injustices within the injustice! Michael Rosen can remember that though he was 'excellent' at English, he was 'poor' at maths and it was only the social nod from the school via the 'Head teacher's recommendation' which secured him a place at grammar school. It was a social decision which secured that: his parents were themselves teachers!

Meanwhile, further injustices were put in place through a falsified admission system which scrubbed out the fact that more girls passed the 11-plus than boys (the distribution of places was rigorously imposed and distributed as 50:50); different localities and regions had different numbers of grammar school places. What was supposed to be a fair, accountable and equal system was a means by which discrimination was officially administered.

\section{Feelings are History Too}

The combination of all these impulses produces, (we feel) an imperative to collect the stories of secondary modern education. This is not simply about 
events or facts. Experience operates on many levels at the same time, political, social, local and emotional. Feelings are history too. Because feelings take place within and as part of, and also as influenced by, local, social and historical conditions, these feelings represent what Raymond Williams called 'structures of feeling' even if they are not perceived as such by the person with the feelings. We hope that bit by bit through the history of the blog we will begin to see such structures. Already the theme of life-long shame is emerging.

Psychologically, this is an example of 'introjection', where the 'victim' administers self-blame where it is the external power-structure which is responsible for the events which have taken place. Though introjection is perceived and felt individually and personally, it is delivered socially, and in this case politically, through the 1944 Education Act. Clearly, it is hard, if not impossible, for many people to say that their reason for shame is a government statute. It is far easier to say, 'I wasn't good enough.' That's how a certain kind of politics works. Again, all the more necessary to gather together these raw experiences so that the people concerned can express them, can know that they are being read and thought about, and that we can all begin to make sense of this huge emotional, social and political event that took place over some 30 years to millions of people.

If this story is unknown or ignored, it will be that much easier for a version of the grammar schools to be reintroduced and imposed. It will happen because not enough people are listening, not enough people know or care about what it felt like to be in the invisible majority who attended secondary modern schools.

As the present government has within it anti-statist elements, it is becoming clear that one route to the reintroduction of grammar schools is to impose these locally. The trick here is for a local 'popular' grammar school to be allowed to expand. In effect, this blights education for the rest of the nonselective schools in that locality. The aim of comprehensive schools was to create all-ability schools so that a whole local community could develop its potential through schools which represented all types no matter how they might be classified according to tests and exams. Subtracting a minority of children from that community, and implying or even stating that they are better and that they deserve some kind of special treatment, divides communities and families with an effect that lasts for life. As many have said, it is also a gift to those families who can afford private tutoring. To save time, places at grammar schools could be awarded to the children of the parents who spend the most on private tutors.

\section{Testimonies}

One note of caution about the testimonies: they do not represent the full range of experiences. They are not 'randomly selected', nor are they a sample culled with particular reference to locality, ability, gender or any other criterion other than that people volunteered to write them. This inevitably puts a bias on what 
is on offer here in a variety of ways. Contributors are self-selecting in terms of having seen the blog's adverts or comments on Twitter, on Facebook, in articles (such as via History Workshop Online) or on comments threads on the Guardian website where Michael Rosen has occasionally posted them. This means that they are literate, computer literate and/or follow either Emma-Louise Williams or Michael Rosen or their followers and social media 'friends' who have commented. It doesn't take long to figure out that this is a highly selective segment of the total population of secondary modern schools of the period. It will not include those unable to read or write fluently or confidently. It will not include those without familiarity with social media or computers. It will not include those who find talking about this matter too upsetting. Put together, the non-inclusion of such people may well prevent us from seeing the full picture of how much damage the secondary modern system caused. Lack of literacy (old or new tech) may well be one of the consequences of that education and yet, for the time being, this blog is not digging these experiences out. Suggestions as to how this can be overcome are greatly welcomed. People scrutinising this will perhaps find other categories which skew the range of comments here, and we would like to hear of these and indeed how to overcome them. Another word of caution: the blog is entirely voluntary, and administered unpaid in EmmaLouise William's spare time.

Below is a sample of edited testimonies:

I passed my $11+(1947)$ but failed the oral examination because I said I wanted to be a 'lady detective', so instead of going to Hastings High School I went to Hastings Secondary Modern School for Girls. There, I was with a few others allowed to study for 0-levels, but mysteriously this 'privilege' was withdrawn from us and we left at 17. I can find no archival records for this school, nor Ministry of Education papers of explanation.

Later, while employed, I took A-level papers and passed - I had to prove my capability, if only to myself. Despite the education authority and a careers adviser who tried to curb my ambition, I became a reporter on a local paper, then a journalist/editor in London, and finally a sub-editor on Woman. After marriage, children and living abroad, I joined the civil service (as a writer/editor) and later a press officer up to retirement.

My husband assures me that my career has been better than many graduates, but I still resent what I perceive as injustice. (Evelyn)

Secondary education in the northern industrial town I grew up in was aimed at producing chemical workers for ICI. The town 'baths' were owned by the company, and that's where we were led once a week to learn to swim. This was in the 1950s and 1960s. In the primary school we were 'streamed' and I was in the 'B' stream, and so destined to fail the 11-plus because only people in the ' $\mathrm{A}$ ' stream went to the single-sex grammar school. 
Surprisingly (maybe the quota had been reached) five of the 'A' stream boys also failed and ended up, like me, at the dual-sex secondary modern. (I don't know about the girls, at that stage they were beyond my event horizon).

The only preparation I had for the 11-plus exam was to be given three brand-new pencils and a map of the 3 miles to get to the venue. There were few cars in those days, so it was a long walk on a Saturday morning.

We were, however, given the choice of which secondary modern school we preferred if we failed, but no-one in the Local Authority took any notice; I was sent to the closest one.

The secondary modern school was built in the twentieth century, but had been outgrown by the post-war baby-boomer child population, so half the playground was taken up with 'temporary' buildings with asbestos roofs. The toilets were also outside and there were no washing facilities.

The school playing fields were 4 miles away and we had a bus to get there but had to walk home after 'playing' games. Often it was so cold that it was impossible to get dressed in the windswept field (the changing room being a pile of bricks inhabited by werewolves); fingers couldn't do up buttons. That turned me off playing organised sport for life. Later the local authority somehow managed to convert a field of allotments into a small athletics track and cricket field, next to the school. By then I had no interest, apart from what happened to the butterflies. (Ian)

I recently celebrated my 69 th birthday and have been reflecting on my life in the form of a scrapbook; writing about my upbringing, school, working years etc.. Whilst compiling memorabilia and photos for this project I realized that unbeknownst to me, for years I have withheld giving any information pertaining to my school years to anyone but never knew why...

I do NOT remember taking the 11+ exam (I didn't even know it had a name), but it has been embedded in my brain and has haunted me for all of these years that I failed a test in school when I was quite young that obviously dictated whether I would be offered the opportunity to further my education in a positive way, or rather be stifled educationally due to failing an obvious flawed exam at the tender age of 10, which favored from what I've been reading, children from a more affluent background than myself, that environment was also a factor, and yes, could it have also been because I was female? (Carol)

I adored my Primary School, the female headteacher, was a Cambridge MA, who had been Steiner trained. My mother was 
better educated and more middle class than my father, who was very working class but hugely intelligent. I had a thirst for knowledge from as early as I can remember and my mother taught me to read and write at the age of 3 and the head allowed me to start at age 4. I enjoyed studying for the 11 plus, I loved the challenge of it all. My teacher was keen for me to go to the Grammar School (the High School for Girls) and told my parents that I had the ability to pass.

I passed all the written exams but had to go for an interview at the Grammar School, as there weren't enough places that year. The interview was appalling for a child of that age. I stood alone before the board of governors and the headmistress. I couldn't understand why they were asking me the questions they were - what newspaper did my parents read? What did my father do? Did my mother work? Did we own our house or was it a council house or rented? Where did we go for our holidays? What did we call our midday meal? They asked me very little about myself; what do I want to do when I grow up? I wanted to go to university and teach and do research, but I didn't feel they believed me. When the letter came saying I hadn't got in, my parents accepted it, although my mother was very cross and blamed herself for 'marrying down'. My headteacher wanted to take it up with the local authority as she was appalled, but my parents said to let it drop.

My first day at the school was horrendous, I had never met such rough kids before and was totally confused. The teachers seemed to be hostile and unfriendly and not to like being there.

I very rarely speak of my secondary school days to anyone. I was bullied from that first day until the day I left. I was beaten up, burnt with cigarettes, sexually assaulted by other girls and ostracised. I told my mother after a year about the bullying, I thought she would get me moved. In fact she gave me a slap and told me never to mention it again or to anyone else. I think she just couldn't handle the guilt or something. I never trusted her again to help me in life and we drifted apart in closeness from that day onwards. At age 14 I tried to commit suicide several times.

The school had absolutely no expectations for any of us. Teachers endlessly told us we were 'rubbish' and 'the dregs' and that we were destined for the jam factory (which employed large numbers locally) or fruit picking. Most kids mucked about in class and barely any teaching went on. We had to take the pointless CSE exams. Most kids left after those; they didn't offer anything else beyond a few $\mathrm{O}$ levels if a teacher fancied teaching them.

I did O levels - English Lit and Language, History, Art and Needlework. The local authority allowed me to transfer to A level college after that, but really I was restricted in which ones I could take because of the O levels I had. I was very depressed at that 
college and found it increasingly hard to trust people and make friends. It makes me weep when I think what a friendly, out going child I'd been at Primary School. I got a place at University, but my parents wouldn't let me go. They thought I would be rejected at university due to my social class. I was allowed to go to teacher training college instead, as this would at least give me a proper job at the end. I had a breakdown at college and the college doctor refused to sign me off as medically stable in order to teach. I worked for years in low paid jobs, totally lacking in confidence. After marriage, I did a degree through the Open University, then three postgraduate qualifications at another University. Eventually I taught on a degree course for over a decade; I now teach workshops as well as mentoring students who have mental health issues. I have achieved a lot in life through hard work and determination. I still feel angry about things that never should have happened. What about all the other kids out there that never got a chance.

(Anonymous)

I moved to a junior school in the south of England in 1964 from Scotland and joined the last two terms. I had already been to 4 different schools before so was used to being the new girl. Nothing prepared me for what was to come.

I was given a number 48 which was the number of girls in the class. I couldn't understand their accent and they couldn't understand mine. I hated it. I tried a bit of school refusing but after a few days of being taken to the school in tears by my father I realised it was futile.

Everyone else had done their 11 plus and knew which school they were going to be going to. One day I was taken into the head's office and sat down in front of her to do the test that I was told would decide if I were to go to the grammar school or not. She watched everything I wrote for what seemed like hours. Some weeks later I was told I had failed. I didn't tell anyone at school as the shame was too much.

Day 1 at the secondary modern was another shock. Not only had I failed but I had failed so badly I was put into the 3rd out of 4 classes. The work seemed trivial and undemanding. A month or so later I was unexpectedly moved to the top class. I was told if I did well enough and came top in the end of year exams I might be moved to the grammar school.

I worked hard and got really good marks in all my tests, except for needlework where I was second from bottom and art where I came bottom of the class. I came top in maths, science, French etc. There was nothing to be done: I couldn't be moved. I was told if I was capable I would be able to do GCEs rather than CSEs. I did 
well over the years in my exams. The French teacher allowed me to join the higher class sometimes and I took French GCSE in my 4th year.

One day in the French class we had to write down our plans for the future and it was my turn to read them out to the class. I said I wanted to go to university. That was a big mistake. The French teacher told me and the class that not one of us was bright enough to do that. So I kept quiet about what I might want to do. I was pleased to be able to do maths, chemistry, English and biology at GCE level. The biology was crazy ... I had followed the CSE lessons only to find a week before the O Level exam that the curriculum was for human biology and the level I had been entered for was biology ... I had done no plant biology at all! And so I failed, similar for physics ... but I came away with CSE grade 1's and 5 O levels.

I made no friends at the secondary modern and kept myself to myself. Others taunted me for being a swot. I didn't try very hard but remained an outsider. I went on to the 6 th form college, which was at the grammar school. Without the basic $\mathrm{O}$ levels it was always going to be hard, but I ended up after 3 years there with some decent A levels ... re-sitting in the 3rd year in zoology (I never did plant biology), maths, and physical science. I applied to study medicine and after my third attempt to get a place at clearing failed, I was offered various places to study nursing at a polytechnic, genetics at university etc and then medicine in London!

Now I am coming towards retirement as a GP in north east England. I qualified in 1979 without any difficulty and have enjoyed a continuous career ever since. The schooling is something I regret. I never had an academic school background which I would have loved. Despite my failure in needlework and art those are both hobbies I now have and have done some creative work in both. Perhaps the constant failure made me more determined to succeed. My experience of school in a non-caring, non-academic surrounding has helped in my understanding of patients in working class areas, but I feel I missed out on a lot. There is lots more to say, but writing this has in some ways helped. (Christina)

My parents were both university graduates, and I think they were much more disappointed that I didn't go to the grammar school than I was. All through my schooling, it was just assumed that I'd go to university, and my parents did their best to keep my nose to the grindstone. They failed, as I was pretty idle. I had quickly learned that I could come near the top of the class by doing a little work in the run up to the annual class exams. I thought that was pretty cool, but actually I was letting myself down and it caused me problems later in life. 
I think the head was pretty ambitious for the school. I don't remember there being any drama, but there were annual Gilbert and Sullivan performances, and regular Spoken English and Spoken French competitions, and a school magazine produced annually with contributions from the pupils.

The school encouraged us, too. The A stream pupils were expected to take up to $8 \mathrm{GCE}$ O-levels, and the average pass rate for the class was about 5 . The pupils in the upper B stream also took Olevels, though fewer. I didn't know many of the pupils in the other streams, and have no idea how many O-levels they took or passed.

I passed 8 O-levels in my fifth year, and, with one other boy, transferred to the local grammar school. I thought I'd stand a better chance of getting decent A-levels there, though I suspect that was not true. No idea now, of course.

I did minimal work at the grammar school and of the 4 A-levels I took, only actually passed Biology and General Studies, gaining Olevel passes in Chemistry and Physics, so two years and no progress there! I went on to a Technical College to retake Chemistry and Physics, passing them well enough to get into university, where I idled away a further 3 years and scraped a third in Biological Sciences. I have never used my degree in any professional capacity, though my wife is a biologist, so it was useful in that respect!

I did enjoy my time at the secondary modern, though looking back, I realise I was very snobbish about the school and my fellow pupils. I figured I was going to university, and few of them had any such ambitions. I didn't mix with them socially much, either.

I still think streaming is the right way to go in education, though I disagree with the gulf that divided secondary modern from grammar schools. (Anonymous)

The rejection Letter arrived one morning and within minutes my friend's mother was at the door checking on my result, and crowing delightedly as her son had passed for the Grammar school. I was destined for the local secondary modern school. The promised bicycle for passing was no more, instead I was offered a consolation prize; a corgi toy guided missile with soft rubber tip on a launching truck in canary yellow as I remember it. (Anonymous)

Many of my junior cohorts, well the boys that is, were also destined for the sec mod school. Thus we all ended up one September morning nervously filing into what seemed a very large hall. The building was pre war and low level. There was a main entrance in the centre and two large squares of class rooms led off from this, one side for boys the other for girls. Our entrance being at the extreme edge of the square and as far from the girls as could be arranged and 
never the twain did meet. There were roughly 450 boys in our school. Classes were streamed by ability, the $G$ stream being the top or most academic and a lower strata or T stream, not sure what the $\mathrm{T}$ stood for, Technical perhaps? Bullying was a massive problem. There was a north playground which was for first years only and was strongly segregated for our own protection. There was a humiliating ritual called The Block, and older boys would pass in the corridor and ask if we had been 'blocked' yet. Blocking consisted of a public beating while hung face down over the low walls which separated the class room corridors and surrounded the square of the senior playground.

The recently arrived headmaster had notions of turning the school into an imitation public school in model and manner. The school was divided into four houses; Mallory, Scott, Wingate, and Nelson for the purposes of inter school competition sports etc. He wore a black gown and was a strict disciplinarian, caning boys regularly on slight pretexts and handing out detentions. The staff was either elderly and near retirement, or else were ex soldiers. Corporal punishment was administered by them also, as well as by the Head: in most cases a few smacks with an over large gym shoe or plimsoll or a simple tweak and pull of the hair and a rap with a knuckle on the side of the head or a thrown missile such as a blackboard rubber.

There was an assembly every morning. Times tables we learned by rote at the beginning of every maths class. We read various classic books and attempts were made to teach us to play the recorder. French classes were taken in the same class room as Spanish classes and with the same teacher. The G stream doing French, the T stream doing Spanish (supposedly easier). The French teacher was at least enlightened enough to use Tintin books as French text books, and so I was exposed to their graphic beauty which was most influential.

One of our form teachers was an elderly Christadelphian who on Friday afternoons would read aloud to us for an hour while we followed the text as he read. His religion prevented him from taking the Lord's name in vain, and so he censored any such moments as he read, thus when reading H G Wells' The Invisible Man he would exclaim, 'Oh gosh', instead of the 'Oh God', which we could clearly see printed in the book in front of us.

There were few facilities such as showers etc. After Gym class we were expected to shower by splashing ourselves from the wash basins in the cloak room, watched often by the Head. During our second year the Head was absent, through illness and the deputy head, a metal work teacher ran the school. After six months of this a court case against the Head appeared in the local paper. Boys had 
been abused by the head and he was sent down. The paper was hidden from me by my parents. No one asked any of us if we too had suffered any abuse. It was never referred to again. If any of us were bold enough to mention it we were promptly told to shut up.

A new Head was appointed. He was an entirely different character from the previous head. He had an abiding love of Shakespeare and drama. His first job was to encourage older boys to get involved in putting on a school play something which had never been attempted.

The art teacher at the school was a maverick figure an exotic refugee from the Hungarian uprising of 1956. Along with the head he encouraged me to go to Saturday painting classes at the local Art School.

I took only two GCE's. We were only put in for exams which it was felt we would definitely pass. I took English and Art both of which I have survived on ever since. Few boys went on to further education. I was one of the luckier ones and ended up in 1963 attending the local Art College full time.

Like most school experiences Sec Mod was a mixed bag. The bullying from staff and older boys was genuinely terrifying at times. The lack of any feminine presence was keenly felt, girls remained unattainable, a mystery. The place stank of cheesy masculinity of the worst kind. The saving grace was being encouraged to follow your own path if you showed the slightest aptitude, the pressure of exams was slight if not nonexistent, and the new and enlightened head was an enabler of the best kind who literally saved my life. (Anonymous)

Since 2012, the blogspot has had approximately $100 \mathrm{~K}$ site visits and received in the region of 90 respondents. It can be found at:

http://secmod.blogspot.co.uk

MICHAEL ROSEN is an award-winning writer and broadcaster, former Children's Laureate and Professor of Children's Literature at Goldsmiths, University of London. He presents Radio 4's acclaimed series about language, Word of Mouth, writes a monthly education column for the Guardian and has campaigned over the last 30 years for fair state education for all. His memoir, So They Call You Pisher! (Verso), recalls his family's East End lives and the first twenty-three years of his own life.

EMMA-LOUISE WILLIAMS is a radio producer and film-maker. Programmes on BBC Radio 3 and 4 include: $A$ Place for $U s$, about the experiences of unaccompanied asylum-seeking teenagers in London; $A$ Story I Am In, about Jamaican British poet James Berry; Crossing the Border, which explored the 
relationship between film and poetry; and, with Michael Rosen, Zola in Norwood, about the novelist's brief period of exile in South London. Forthcoming with BBC Radio 4 are The First Jazz Poet and The American Art Tapes.

Michael Rosen and Emma-Louise Williams are co-curators of The Working Artist: the East London Group, at the Nunnery Gallery, Bow.

Correspondence: emmalouisew@hotmail.com 
